\title{
Genesis and Quality of Groundwater in the Southeastern Region of Southern Vietnam
}

\author{
Chau Tran Vinh ${ }^{1}$, Tran Hong Thai ${ }^{2}$, Doan Van Canh $^{3}$, Dang Duc Nhan ${ }^{3}$, Nguyen Cao Huan ${ }^{4}$, Nguyen Van Nghia ${ }^{1}$ \\ Nguyen Hong Hieu ${ }^{1}$ and Trinh Thi Thu Van ${ }^{1}$ \\ 1. Department of Water Resources Management, Ministry of Natural Resources and Environment, Hanoi 100000, Vietnam \\ 2. National Meteorological and Hydrological Center, Hanoi 100000, Vietnam \\ 3. Hydrogeology Association of Vietnam, Hanoi 100000, Vietnam \\ 4. Department of Geology, Hanoi University of Natural Sciences, Hanoi 100000, Vietnam
}

\begin{abstract}
The origin and quality of groundwater in the Southeastern region (belongs to Southern Plain) were identified by using isotopic techniques and geochemical analysis. Groundwater samples were collected from 7 aquifers: the Holocene, upper Pleistocene, middle Pleistocene, lower Pleistocene, upper Pliocene, middle Pliocene and Miocene aquifers. The water isotopic compositions $\left(\delta^{2} \mathrm{H}\right.$ and $\delta^{18} \mathrm{O}$ ) were determined to elucidate the origin and the interaction between surface water and groundwater studies. Transit time (age) of the groundwater samples was determined to explain the direction of groundwater flow. The dating techniques included ${ }^{3} \mathrm{H}$ and ${ }^{14} \mathrm{C}$ isotopes measurement, followed by a correction for the initial ${ }^{14} \mathrm{C}$-activity by the ${ }^{13} \mathrm{C}$-composition $\left({ }^{13} \mathrm{C}\right.$ ) in TDIC (Total Dissolved Inorganic Carbon). Geochemical parameters of the groundwater samples were measured either directly in the field or in the laboratory. The results showed that the groundwater from the Holocene and upper Pleistocene aquifers was most recharged from the local meteorological and hydrological systems, including local precipitation, river and reservoirs. Thus, it has short transit time and its stable isotopic composition is spread around the local meteoric waterline and lines for rivers or reservoirs water. The groundwater in the deeper aquifers: middle and lower Pleistocene, and Neogene aquifers has old age up to 22.5 ka BP. Its water seems to be recharged from the areas with an altitude from 600 to $700 \mathrm{~m}$ higher to the Neogene deposit layer altitude. The groundwater in the SE SP (South-Eastern Southern Plain) region has a high quality. The water type is $\mathrm{Na}-\mathrm{Ca}-\mathrm{Mg}-\mathrm{HCO}$ with low content of chloride and TDS (Total Dissolved Solids). Calcite/dolomite and gypsum dissolution, organic matter decomposition and sequence of red-ox reactions proceeding through different electron acceptors sediment were controlled the chemistry of the groundwater in the study region.
\end{abstract}

Key words: Water isotopic composition, ${ }^{14} \mathrm{C}$-dating, groundwater, South-Eastern Southern Plain region, Vietnam.

\section{Introduction ${ }^{1}$}

There were two contrary hypotheses on the genesis of groundwater resource in the SP (Southern Plain). Based on the results of a study conducted during the 1980's, Cuong, N. K. [1] and his co-workers concluded that the artesian groundwater in the SP is paleo-type, being closely-buried since the Plain was formed and this water has no recharge. However, there was another hypothesis that the origin of groundwater in the SP was recharged from the precipitation and surface sources with a very slow rate [2].

Corresponding author: Chau Tran Vinh, master, research field: hydrogeology.
There was a study on groundwater in the Mekong River Delta, the western region of the SP, using stable water isotopes and dating the water by the radiocarbon method to determine possible recharge areas to aquifers in this region. The results of the study indicate that groundwater in the study area is recharged from areas at an altitude of around $170 \mathrm{~m}$ above the mean sea level. The recharge areas could be the northeast highland, i.e. the Highland Plateau and/or the Cambodian territory [3].

The aim of this study is to investigate in details the origin and quality of groundwater from the most important aquifers in the northeast region of the SP. 
The techniques used in this study include the determination of water stable isotopic compositions $\left(\delta^{2} \mathrm{H}\right.$ and $\left.\delta^{18} \mathrm{O}\right)$ and chemical compositions in different sources of water, namely local precipitation, rivers water and groundwater. Water stable isotopic content in conjunction with water ionic content can be used to identify the groundwater origin, evaporation, stalinization, desalination and mixing processes that affect water bodies [4]. In addition, the use of radioactive isotopes of minerals dissolved in water, e.g. ${ }^{14} \mathrm{C}$ in the TDIC (Total Dissolved Inorganic Carbon) to date groundwater samples, could offer an idea about the movement direction of groundwater and the interaction between aquifers in the study region [5].

\section{Study Site}

The study site was the northeast region of the Southern Plain of Vietnam which consists of Ho Chi Minh municipality and Tay Ninh, Binh Phuoc, Binh Duong, Dong Nai and Ba Ria-Vung Tau provinces. Nowadays, these areas are very actively developed in both agricultural and industrial activities. Water for domestic use and production is now extracted from groundwater from deep aquifers [6].

\subsection{Climate in the Region}

The climate in the region is dominated by monsoons. The climate characteristics in this area are: The southwest monsoon usually continues in force until November, with rains occurring almost daily during this season [7]; Rainfall during the southwest monsoon is usually about $1,750 \mathrm{~mm}$ a year; Temperatures are high everywhere in the region during this season and usually are above $26{ }^{\circ} \mathrm{C}$; During the period, November to March, the weather in the region is generally dry and relatively cool; The monthly average rainfall and temperature during the dry season is about $30 \mathrm{~mm}$ and $23-24{ }^{\circ} \mathrm{C}$, respectively.

\subsection{Geology and Hydrogeology of the Region}

The entire SP is one of the 5 geologic structural blocks which created the terrestrial Vietnam. The northeast and northwest blocks are located in the northern part; Truong Son and Kon Tum blocks are in the central part; and SP block is in the southernmost part. The SP block was covered with a very thick (> 6,000 m) sequence of Cenozoic formations deposited in a continental drift. A hydrogeological cross-section drawn across the transect II-II of the SENB (Southeastern of Nam Bo Plain) region is depicted in Figs. $1 \mathrm{a}$ and $1 \mathrm{~b}$.

During the Mesozoic, many such graben structures were formed and become basins for sedimentation [8, 9]. The Neogene and upper Paleogene are the main deposits found in the SP geologic block and they belong to the deltaic and marine sediment while basalts are found in the SE SP (South-Eastern Southern Plain) region. Table 1 shows the geological characteristics and aquifers of the entire SP and the SE $\mathrm{SP}$ region $[10,11]$.

\subsection{Hydrology}

The hydrologic regime of the SE region is dominated by the Sai Gon-Dong Nai River system (Fig. 1c). The Dong Nai mainstream has a length of 628 kilometers and it creates a $37,500 \mathrm{~km}^{2}$ basin. The total reservoir storage capacity in the Dong Nai River basin is 5.1 billion $\mathrm{m}^{3}$ [12]. The Sai Gon River basin has an area of $4,500 \mathrm{~km}^{2}$ in which the water storage capacity was estimated to be around $6 \mathrm{MCMs}$ (Million Cubic Meters) [11].

The largest irrigation system in the Sai Gon-Dong Nai River basin is the Dau Tieng irrigation scheme on the Sai Gon River that was completed in 1985. The Dau Tieng reservoir has an effective live storage of 1.1 billion $\mathrm{m}^{3}$ and a maximum surface area of 27,000 ha. Its volume is 105 million $\mathrm{m}^{3}$ to supply water for irrigation and clean water in the Tay Ninh province and Ho Chi Minh city. The lake also contributes to pushing back the salinity because it frequently discharges water to the downstream of Sai Gon River with the discharge of $20 \mathrm{~m}^{3} / \mathrm{s}$. 


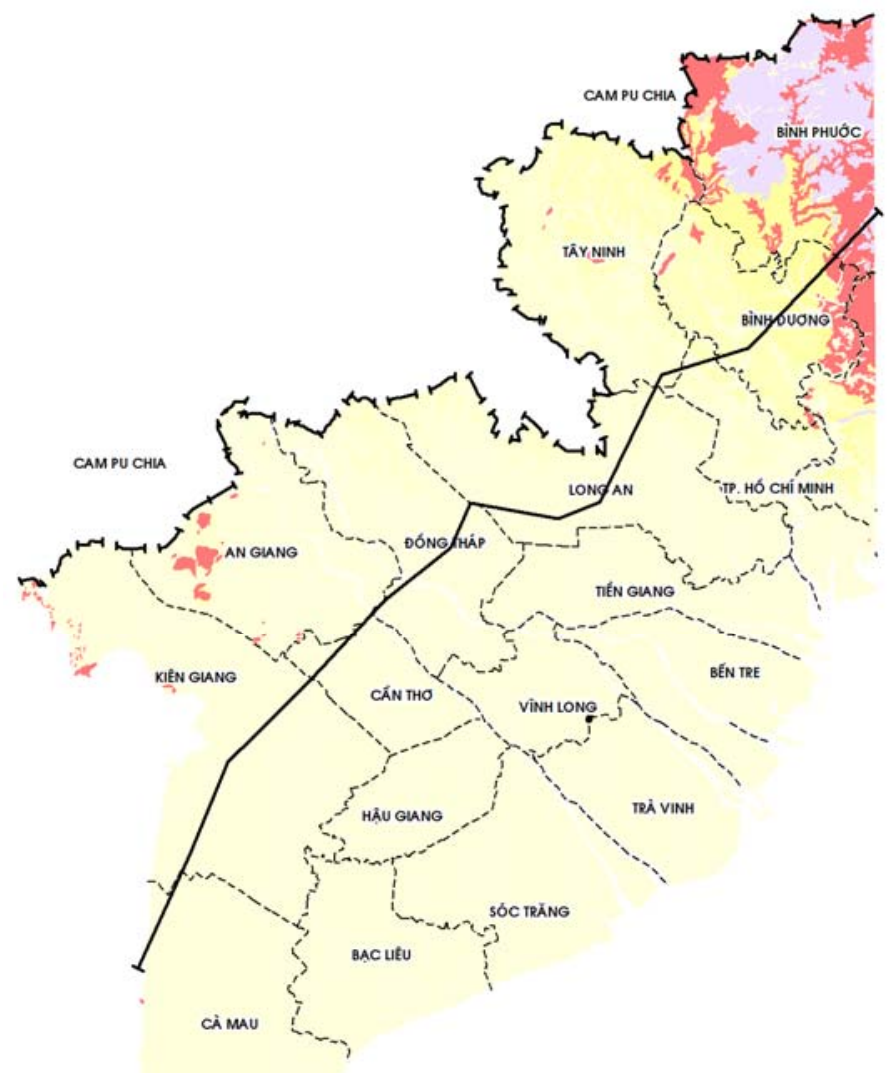

Fig. 1a Diagram of across sections of the Southern Plain.

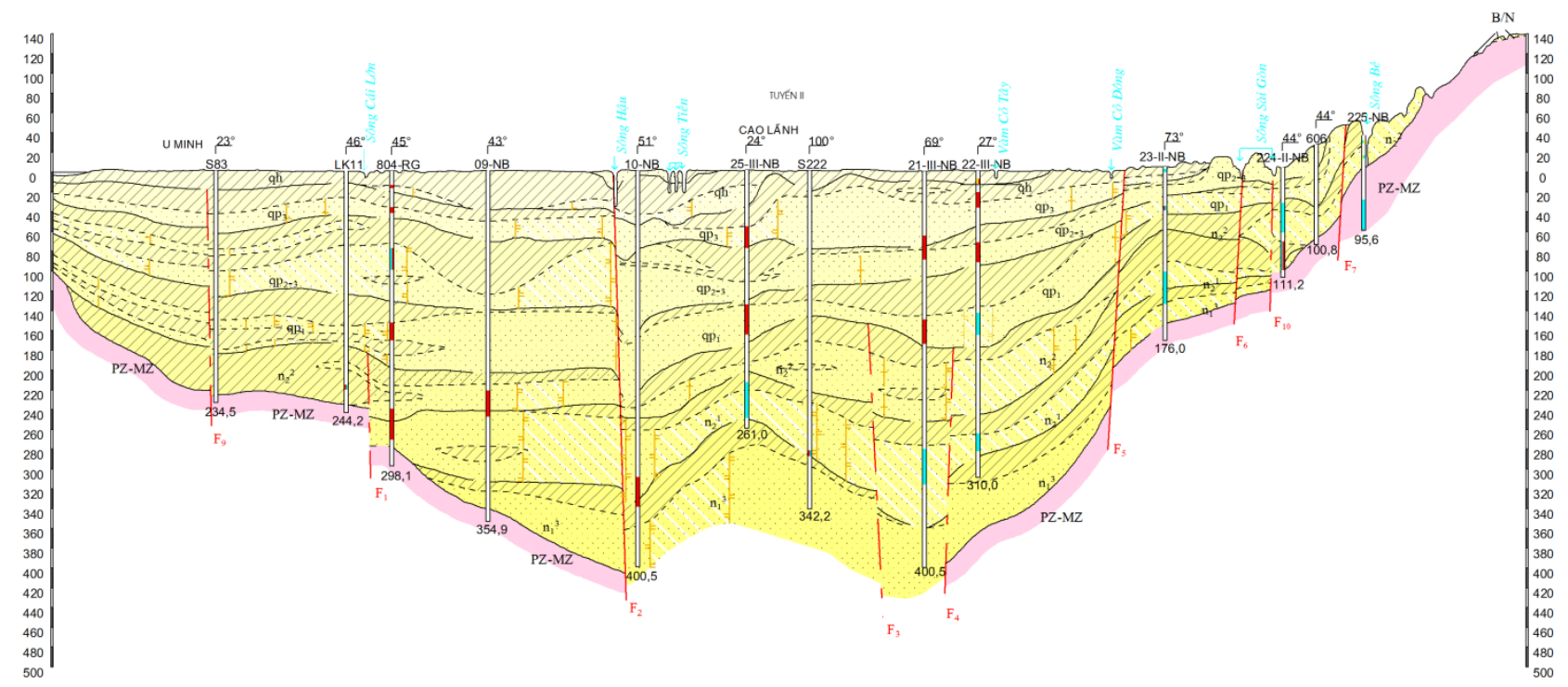

Fig. 1b A cross-section II-II of the aquifers of the Southern Plain. 
Table 1 Geological characteristics and aquifers in the SP and SE SP region.

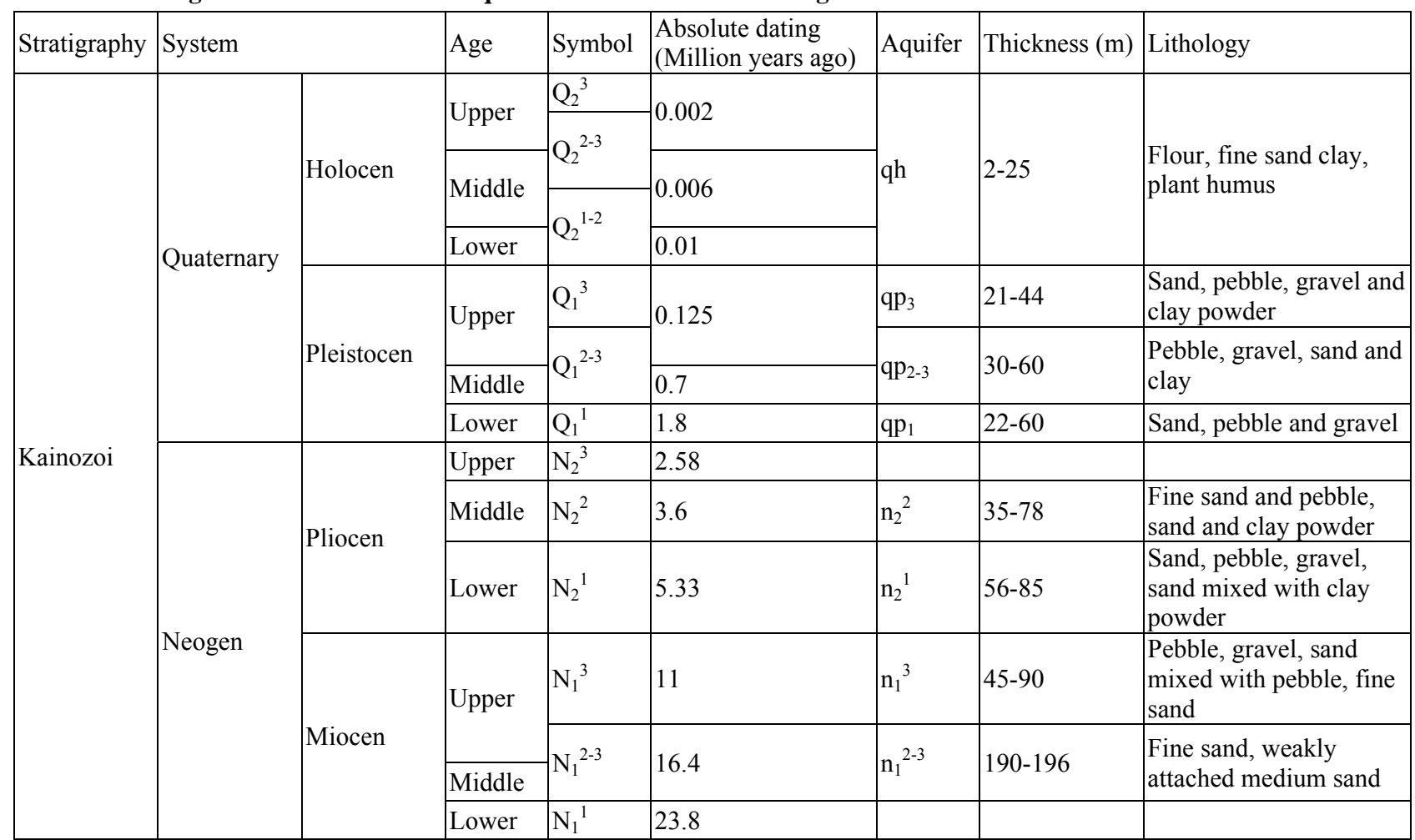

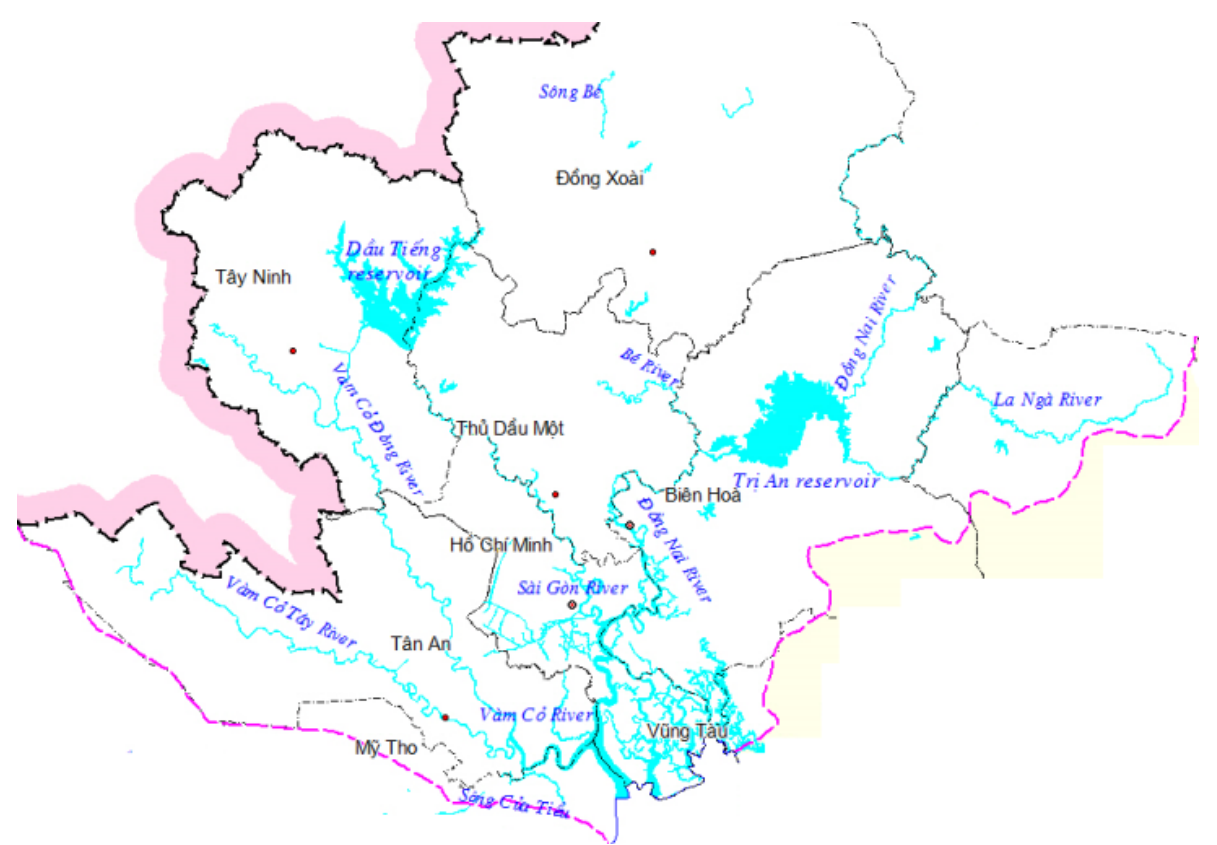

Fig. 1c Map of Dong Nai-Sai Gon River basin.

\section{Methods}

\subsection{Sampling Locations and Sampling Procedure}

Fig. 1d depicts a map of sampling locations. Totally, 39 groundwater samples were sampled in the dry season (Mar. 2015) and rainy season (Aug. 2016) for this study. The samples were taken from 7 aquifers: Holocene (he), upper Pleistocene ( $\mathrm{qp}_{3}$ ), middle Pleistocene $\left(\mathrm{qp}_{2-3}\right)$, lower Pleistocene $\left(\mathrm{qp}_{1}\right)$, upper Pliocene $\left(\mathrm{n}_{2}^{2}\right)$, middle Pliocene $\left(\mathrm{n}_{2}{ }^{1}\right)$ and Miocene $\left(\mathrm{n}_{1}{ }^{3}\right)$. 


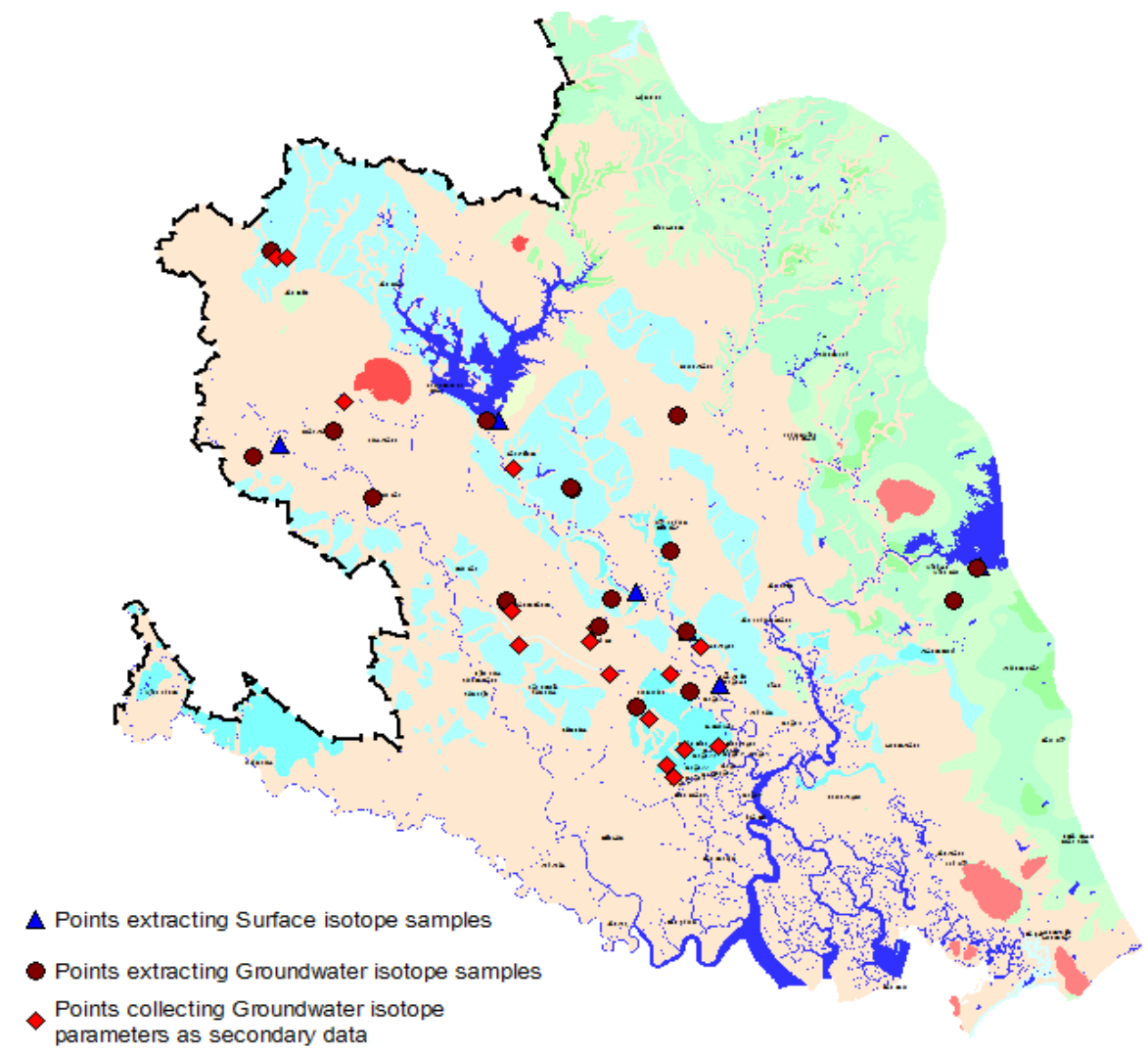

Fig. 1d Isotopic sampling sites in the South East region.

The water level of the aquifers in each sampling location was measured using an automatic logger (Solite, Canada). Five borehole volumes were flushed before taking the samples. A flow cell equipped with probes for $\mathrm{pH}$ and EC (Electrical Conductivity) was mounted directly on the sampling tube. During flushing, the EC, $\mathrm{pH}$ and temperature were determined after each emptied borehole volume to ensure that stable values were obtained. The measurements were carried out with a WTW Multi197i multi-purpose instrument using a WTW Tetracon 96 EC probe, a WTW SenTix 41 pH electrode.

Alkalinity was determined shortly after sampling by the Gran-titration method [13]. DIC (Dissolved Inorganic Carbon) is used to determine the content of ${ }^{13} \mathrm{C}$ and ${ }^{14} \mathrm{C}$ needed for the radiocarbon dating of groundwater. DIC was precipitated in the form of $\mathrm{BaCO}_{3}$ from around 100 liters of groundwater at $\mathrm{pH}$ 10 using saturated $\mathrm{BaCl}_{2}$ solution. Ferrous ion concentration $\left(\mathrm{Fe}^{2+}\right)$ in water samples was determined by colorimetry using a HachDR/2010 instrument and Ferrozine method [14].

Around $100 \mathrm{~mL}$ of groundwater of each sample was first filtered through $0.45 \mathrm{~m}$ mesh filters to remove suspended matters then split into two parts. One part was acidified with $\mathrm{HNO}_{3}(65 \%$, PA grade, Merck, Germany) to a $\mathrm{pH}$ of about 1-2. These samples will be used to analize the cations $\mathrm{NH}_{4}^{+}, \mathrm{Na}^{+}, \mathrm{K}^{+}, \mathrm{Ca}^{2+}$ and $\mathrm{Mg}^{2+}$. The remaining part was kept without acidification for $\mathrm{Cl}^{-}, \mathrm{NO}_{3}{ }^{-}$and $\mathrm{SO}_{4}{ }^{2-}$ analysis. All the samples were refrigerated until analysis in the laboratory.

Rain water was collected on a monthly basis for the 2015 and 2016 using a device constructed following an IAEA (International Atomic Energy Agency) recommendation [15]. The device was installed at the roof of the premises of the Dau Tieng Reservoir Management Office. Surface water from the Dau Tieng, Tri An reservoirs, from Sai Gon and Dong Nai rivers was also sampled on a monthly basis in the 
same day when the rain water was collected. The surface water sample was taken at $0.5 \mathrm{~m}$ depth from the surface and around $2 \mathrm{~m}$ from the bank of the reservoirs and rivers. Rain water, surface water and groundwater samples for the stable isotopic composition determination were stored in HDPE (High-Density Polyethylene) bottles of $50 \mathrm{~mL}$ capacity with double caps.

For the tritium determination, one liter of surface water and groundwater in the Holocene and upper Pleistocene aquifers was sampled into HDPE bottle with a tight cap to avoid the isotopic exchange with the atmospheric moisture. The samples were transferred to the laboratory in Hanoi for further treatment and measurement for tritium activity.

\subsection{Sample Treatment in the Laboratory and Analytical Procedure}

The ionic content of water samples was quantified by ion chromatography using a Dionex 600 of the INST (Institute for Nuclear Science and Technology) in Hanoi. Stable isotopes $\left(\delta^{2} \mathrm{H}, \delta^{18} \mathrm{O}\right.$ and $\left.{ }^{13} \mathrm{C}\right)$ were analyzed at the INST on an IR MS (Isotope Ratio Mass-Spectrometer, Micro Mass, JV, UK) equipped with an Elemental Analyzer (Eurovector, Italy). To determine deuterium composition in water, the samples were under pyrolysis on Ni-powder catalyst at $1,050{ }^{\circ} \mathrm{C}$ to form hydrogen, followed by a purification on a chromatographic column before entering the ion source of the IR MS. The water oxygen was first converted into $\mathrm{CO}_{2}$ gas by decomposing the water samples on glassy carbon at $1,250{ }^{\circ} \mathrm{C}$, followed by a chromatographic purification of $\mathrm{CO}_{2}$ gas before its entering the ion source of the IR MS.

Upon the arrival to the laboratory, the Barium carbonates were carefully washed off with hot deionized water to remove the alkaline excesses then dried under a vacuum. The dried carbonate samples with an amount of around $100 \mathrm{mg}$ were then wrapped in tin capsules and subject to decomposing at $1,250{ }^{\circ} \mathrm{C}$ on the $\mathrm{CuO}_{2}$ catalyst in the Elemental Analyzer. The formed $\mathrm{CO}_{2}$ was then allowed passing through a chromatographic column to remove any contaminant before entering the ion source of the IR MS for the ${ }^{13} \mathrm{C}$ content determination. The water stable isotopic composition and ${ }^{13} \mathrm{C}$ content in DIC was expressed in the delta notation as Eqs. (1)-(3).

$$
\begin{aligned}
\delta^{2} H & =\left(\frac{R_{2_{H, \text { sample }}}}{R_{2_{H} \text {,std }}}-1\right) \times 1000 \\
\delta^{18} O & =\left(\frac{R_{10_{0}, \text { sample }}}{R_{18} \text { o,std }}-1\right) \times 1000 \\
\delta^{13} C & =\left(\frac{R_{13} \text { C,sample }}{R_{13} \text {, std }}-1\right) \times 1000
\end{aligned}
$$

where $R_{2_{H, \text { sample }}}, R_{2_{H, s t d}}, R_{18_{O, \text { sample }}}, R_{18_{O, s t d}}$, $R_{13_{C, \text { sample }}}$ and $R_{13_{C, \text { std }}}$ are the isotopic ratios of ${ }^{2} \mathrm{H} /{ }^{1} \mathrm{H},{ }^{18} \mathrm{O} /{ }^{16} \mathrm{O},{ }^{13} \mathrm{C} /{ }^{12} \mathrm{C}$ of samples and standards, respectively. The value of delta notation is expressed in per mil (\%o). The standard used in the analyses of water stable isotopes is VSMOW (Vienna Standard of Mean Ocean Water), but that for ${ }^{13} \mathrm{C}$ in DIC is VPDB (Vienna Pee Dee Belemnite) [16].

The precision of $\delta^{2} \mathrm{H}$ was better than $\pm 2 \%$ and that of $\delta^{18} \mathrm{O}$ and ${ }^{13} \mathrm{C}$ was $\pm 0.2 \%$. A quality assurance and quality control program was applied for the ionic content determination by analyzing standard solutions supplied by the IC (Ion Chromatography) supplier. The standard deviation of the analytical results was better than $\pm 5 \%$ from the certified value for respective constituent.

For the tritium measurement, the water samples were first subject to distillation to remove the minerals dissolved till the $\mathrm{EC}$ was less than $10 \mathrm{~S} \cdot \mathrm{cm}^{-1}$. Around $500 \mathrm{~mL}$ of the distilled water samples were then subject to the electrolytic enrichment for tritium at 4 ${ }^{\circ} \mathrm{C}$ till around $10 \mathrm{~mL}$ was attained [17, 18]. The tritium enriched water samples were purified and then mixed with low tritium Ultimagold scintillation cocktail (HP Supplier) in vials of $20 \mathrm{~mL}$ capacity to count for the ${ }^{3} \mathrm{H}$ activity on a low background HP Liquid Scintillation Counter TriCarb TR 3700 . The ${ }^{3} \mathrm{H}$ activity in water samples was expressed in the $\mathrm{TU}$ 
(Tritium Unit, $1 \mathrm{TU}=0.118 \mathrm{~Bq} \cdot \mathrm{L}^{-1}$ ). The limit of detection for ${ }^{3} \mathrm{H}$ by the procedure was estimated to be as high as $0.4 \mathrm{TU}$. The accuracy of the determination was checked by the participation in the intercomparison exercises of the TRI-2004 and TRI-2008, organized by the IAEA Isotope Hydrology Section in the years of 2004 and 2008 [19, 20].

The ${ }^{14} \mathrm{C}$ analysis was conducted in the Center for Nuclear Techniques in Ho Chi Minh city. There the $\mathrm{BaCO}_{3}$ was decomposed with the concentrated $\mathrm{H}_{3} \mathrm{PO}_{4}$ (PA grade, Merck supplier) to get $\mathrm{CO}_{2}$ for further benzene synthesis [21-24]. The benzene obtained was mixed with Ultimagold scintillation cocktail (HP Supplier) and then counted for the ${ }^{14} \mathrm{C}$ activity on the HP LSC TriCarb TR 3770. The ${ }^{14} \mathrm{C}$ content in samples was expressed in PMC (Percent of Modern Carbon). This is a relative measurement of ${ }^{14} \mathrm{C}$ activity in samples and those in a standard supplied by the NIST (National Institute of Standards and Technology, USA). The ${ }^{14} \mathrm{C}$ NIST standard used in this study was oxalic acid II (ox-II), made from French beet molasses planted in 1977 [25].

\subsection{Groundwater Transit Time (the Age) Estimation}

Age of groundwater is defined as the transit time between the area receiving recharged infiltration and the outlet point from an aquifer [26]. The aim of the age determination is to evaluate the flow direction of water in an aquifer. The groundwater age calculation was made based on the data of ${ }^{14} \mathrm{C}$ activity and ${ }^{13} \mathrm{C}$ in the DIC. The principle of the ${ }^{14} \mathrm{C}$-dating method was the law of radioactive decay and in the case of dating for groundwater. It was expressed by the Eq. (4).

$$
{ }^{14} t=8268 \ln \frac{{ }^{14} a_{\text {in }}^{0}}{{ }^{14} a_{\text {sample }}} \times(\text { (a BP) }
$$

where ${ }^{14} t$ denotes the age, in years before present (a BP) of a groundwater sample estimated by the ${ }^{14} \mathrm{C}$ activity in DIC; the number 8268 is the quotient of the half live of ${ }^{14} \mathrm{C}$-isotope (5,730 a) to $\ln 2 ;{ }^{14} \mathrm{a}_{\text {in }}^{0}$ is the initial content of ${ }^{14} \mathrm{C}$ in DIC before entering the saturated zone (PMC), and ${ }^{14} \mathrm{a}_{\text {sample }}$ is the ${ }^{14} \mathrm{C}$ content (PMC) in DIC of the sample.

The estimation of the age of groundwater by the Eq. (4) requires corrections for the ${ }^{14} a_{\text {in }}^{0}$ because before entering the saturated zone, carbon in the bicarbonate would participate in the isotopic exchange with carbon in the biogenic $\mathrm{CO}_{2}$ released from the plant root respiration on one hand, and there a new portion of bicarbonate could be formed due to the oxidation of organic matters or dissolution of inorganic carbonates presented in the unsaturated zone, on the other hand. All these processes could modify the value of ${ }^{14} \mathrm{a}_{\text {in }}^{0}$. The correction of an isotope mixing model referred to as complete exchange with $\mathrm{CO}_{2}$ in the unsaturated zone proposed by Gonfiantini, R. [16, 27] for a closed system was applied as Eq. (5).

$$
{ }^{14} a_{\text {in }}^{0}=\frac{\delta^{13} C_{D I C}-\delta^{13} c_{c c}}{\delta^{13} C_{C O_{2, o r g}}-\delta^{13} c_{c c}+\varepsilon_{C O_{2} / D I C}}
$$

where $\delta^{13} \mathrm{C}_{\mathrm{DIC}}, \delta^{13} \mathrm{C}_{\mathrm{cc}}$ and $\delta^{13} \mathrm{C}_{\text {org }}$ are the content of ${ }^{13} \mathrm{C}$, respectively, in dissolved inorganic carbon in a water sample, in calcareous materials and in biogenic dioxide originated from the decomposition of organic matters; $\varepsilon_{c c / D I C}$ is the fractionation coefficient for ${ }^{13} \mathrm{C}$ in the isotopic exchange reaction between carbon dioxide and DIC and is temperature dependent [4, 28].

$$
\varepsilon_{C O_{2} / D I C}=\left(-\frac{9483}{T}+23.89\right) \%
$$

where $\mathrm{T}$ is the temperature of water sample in Kelvin.

In the study area, the $\delta^{13} \mathrm{C}_{\mathrm{cc}}$ was found to be ranging from $1 \%$ to $2 \%$ and the average value of $1.5 \%$ was taken in the correction for the ${ }^{14} \mathrm{a}_{\text {in }}^{0}$. The $\delta^{13} C_{C_{2, \text { org }}}$ in Eq. (5) was taken as high as $-23 \%$ as it is characterized for carbon dioxide generated from the C-3 plants in the tropical areas. Detail for the procedure of ${ }^{14} \mathrm{a}_{\text {in }}^{0}$ calculation could be found in Fontes, J. C. and Garnier, J. M. [29, 30]. The data of the ${ }^{3} \mathrm{H}$ activity were used just to confirm whether the study water sample was old or modern.

\section{Results}

Concentration of major ionic constituents of 
groundwater samples taken in Mar. 2015 (DS, dry season) and in Aug. 2016 (RS, rainy season) from the Holocene, Pleistocene and Neogene aquifers in the SE SP region were presented in Table 1 along with the sampling locations. The isotopic composition of deuterium $\left(\delta^{2} \mathrm{H}\right)$, oxygen-18 $\left(\delta^{18} \mathrm{O}\right)$ as well as tritium activity in water, and the content of ${ }^{13} \mathrm{C}$ and ${ }^{14} \mathrm{C}$ in DIC were presented in Table 2.

As seen from Tables 2 and 3, the deviation of the results for the RS is not exceeded $5-7 \%$ compared to those collected in the DS. Therefore, for more convenient discussion, the results presented in Figs. 2-9 will represent for the dry season only.

\subsection{Isotopic Composition of Water in the Aquifers}

As seen from Table 2, the tritium activity in groundwater from the upper Pleistocene aquifer was comparable with those in surface water ranging from 1.0 to $2.0 \mathrm{TU}$ (Table 2). However, the tritium content in groundwater from the middle and lower Pleistocene, and Neogene aquifers was lower than $1 \mathrm{TU}$, being the level of tritium originated from the reaction of the cosmic neutron with nitrogen in the soil [31]. Water in the lower Neogene aquifer contains a tritium concentration around the detection limit of $0.4 \mathrm{TU}$ of the determination technique.

Table 2 The isotopic composition of groundwater in the aquifer of the Southeast region (dry season).

\begin{tabular}{|c|c|c|c|c|c|c|c|c|c|}
\hline $\mathrm{N}^{\mathrm{o}}$ & Number of works & $\mathrm{Y}(\mathrm{m})$ & $\mathrm{X}(\mathrm{m})$ & Aquifer & $\delta^{18} \mathrm{O}$ & $\delta^{2} \mathrm{H}$ & ${ }^{3} \mathrm{H}$ & $\delta^{13} \mathrm{C}_{\mathrm{PDB}}(\%)$ & PMC (\%) \\
\hline 1 & Q00102AM1 & $1,252,160$ & 644,840 & $\mathrm{qp}_{3}$ & $-6.09 \pm 0.08$ & $-40.4 \pm 1.4$ & $1.73 \pm 0.46$ & $-14.82 \pm 0.22$ & $101.55 \pm 1.97$ \\
\hline 2 & Q00102F & $1,238,343$ & 625,335 & $\mathrm{qp}_{3}$ & $-6.54 \pm 0.06$ & $-40.9 \pm 1.2$ & $1.26 \pm 0.12$ & $-13.61 \pm 0.21$ & $102.71 \pm 1.83$ \\
\hline 3 & Q023020M1 & $1,219,729$ & 648,145 & $\mathrm{qp}_{3}$ & $-6.26 \pm 0.05$ & $-39.2 \pm 1.1$ & $1.02 \pm 0.46$ & $-12.91 \pm 0.28$ & $103.2 \pm 1.12$ \\
\hline 4 & Q02304TM1 & $1,219,729$ & 648,145 & $\mathrm{qp}_{1}$ & $-7.18 \pm 0.1$ & $-46.3 \pm 1.1$ & $0.13 \pm 0.22$ & $-18.57 \pm 0.27$ & $84.7 \pm 1.3$ \\
\hline 5 & Q02304ZM1 & $1,219,729$ & 648,145 & $\mathrm{n}_{2}{ }^{1}$ & $-7.45 \pm 0.08$ & $-49.6 \pm 1.2$ & $0.34 \pm 0.2$ & $-20.09 \pm 0.31$ & $47.76 \pm 2.56$ \\
\hline 6 & Q023050M1 & $1,219,729$ & 648,145 & $\mathrm{n}_{1}^{3}$ & $-7.61 \pm 0.11$ & $-50 \pm 1.1$ & $0.11 \pm 0.34$ & $-21.85 \pm 0.31$ & $44.08 \pm 2.3$ \\
\hline 7 & Q09902B & $1,220,156$ & 666,294 & $\mathrm{qp}_{3}$ & $-6.72 \pm 0.1$ & $-42.9 \pm 1.5$ & $1.07 \pm 0.12$ & $-15.45 \pm 0.26$ & $99.07 \pm 1.97$ \\
\hline 8 & Q22002Z & $1,282,519$ & 607,650 & $\mathrm{qp}_{2-3}$ & $-6.48 \pm 0.12$ & $-43.7 \pm 1.2$ & $1.19 \pm 0.31$ & $-16.03 \pm 0.31$ & $111.52 \pm 1.89$ \\
\hline 9 & Q220040M1 & $1,282,534$ & 607,647 & $\mathrm{qp}_{1}$ & $-6.85 \pm 0.07$ & $-44.7 \pm 1$ & $0.83 \pm 0.34$ & $-23.33 \pm 0.42$ & $96.92 \pm 1.21$ \\
\hline 10 & Q220050M1 & $1,282,538$ & 607,646 & $\mathrm{n}_{2}{ }^{1}$ & $-7.81 \pm 0.11$ & $-52.8 \pm 0.9$ & $0.16 \pm 0.31$ & $-19.22 \pm 0.3$ & $44.43 \pm 2.76$ \\
\hline 11 & Q221020 & $1,250,383$ & 618,306 & $\mathrm{qp}_{3}$ & $-6.24 \pm 0.09$ & $-41.7 \pm 1.2$ & $1.68 \pm 0.22$ & $-18.5 \pm 0.38$ & $100.78 \pm 2.07$ \\
\hline 12 & Q22104T & $1,250,380$ & 618,299 & $\mathrm{qp}_{1}$ & $-7.48 \pm 0.12$ & $-50.1 \pm 1.5$ & $0.33 \pm 0.22$ & $-17.74 \pm 0.34$ & $87.24 \pm 1.05$ \\
\hline 13 & Q22104Z & $1,250,381$ & 618,293 & $\mathrm{n}_{2}^{2}$ & $-7.68 \pm 0.09$ & $-51.9 \pm 1.3$ & $-0.32 \pm 0.23$ & $-16.45 \pm 0.31$ & $43.32 \pm 2.52$ \\
\hline 14 & Q222020 & $1,245,779$ & 604,715 & $\mathrm{qp}_{3}$ & $-6.93 \pm 0.14$ & $-44.1 \pm 0.8$ & $0.96 \pm 0.21$ & $-12.72 \pm 0.3$ & $102.59 \pm 1.82$ \\
\hline 15 & Q222040 & $1,245,789$ & 604,715 & $\mathrm{n}_{2}^{2}$ & $-7.42 \pm 0.11$ & $-47.1 \pm 1.4$ & $0.05 \pm 0.21$ & $-17.3 \pm 0.33$ & $5.93 \pm 1.43$ \\
\hline 16 & Q222050 & $1,245,795$ & 604,714 & $\mathrm{n}_{1}^{3}$ & $-7.08 \pm 0.13$ & $-45.5 \pm 1.3$ & $0.69 \pm 0.29$ & $-18.93 \pm 0.25$ & $95.71 \pm 1.06$ \\
\hline 17 & Q222030 & $1,245,787$ & 604,714 & $\mathrm{qp}_{2-3}$ & $-6.87 \pm 0.08$ & $-44 \pm 1.2$ & $0.84 \pm 0.26$ & $-13.19 \pm 0.34$ & $96.05 \pm 1.22$ \\
\hline 18 & Q224020 & $1,228,842$ & 676,587 & $\mathrm{qp}_{2-3}$ & $-6.6 \pm 0.14$ & $-43.2 \pm 1.3$ & $1.79 \pm 0.12$ & $-14.57 \pm 0.25$ & $105.04 \pm 1.37$ \\
\hline 19 & Q22404T & $1,228,847$ & 676,586 & $\mathrm{n}_{2}^{2}$ & $-7.24 \pm 0.11$ & $-46.6 \pm 1.1$ & $0.37 \pm 0.31$ & $-21.07 \pm 0.4$ & $90.4 \pm 1.29$ \\
\hline 20 & Q804020 & $1,215,192$ & 664,143 & $\mathrm{qp}_{3}$ & $-6.69 \pm 0.12$ & $-39.2 \pm 1.3$ & $1.28 \pm 0.18$ & $-6.3 \pm 0.4$ & $109.85 \pm 3.7$ \\
\hline 21 & Q80404T & $1,215,188$ & 664,143 & $\mathrm{n}_{2}^{2}$ & $-6.81 \pm 0.09$ & $-45 \pm 1.5$ & $0.25 \pm 0.27$ & $-20.34 \pm 0.27$ & $74.01 \pm 2.19$ \\
\hline 22 & Q80404ZM1 & $1,215,188$ & 664,143 & $\mathrm{n}_{2}{ }^{1}$ & $-7.24 \pm 0.12$ & $-48.6 \pm 3.4$ & $-0.11 \pm 0.12$ & $-20.45 \pm 0.24$ & $34.06 \pm 2.53$ \\
\hline 23 & Q00202B & $1,214,366$ & 679,494 & $\mathrm{qp}_{2-3}$ & $-6.74 \pm 0.08$ & $-47.1 \pm 0.8$ & $0.9 \pm 0.1$ & $-15.79 \pm 0.3$ & $95.88 \pm 1.02$ \\
\hline 24 & Q00204A & $1,214,360$ & 679,461 & $\mathrm{qp}_{1}$ & $-6.76 \pm 0.13$ & $-46.9 \pm 1.3$ & $0.13 \pm 0.28$ & $-20.27 \pm 0.52$ & $87.72 \pm 1.21$ \\
\hline 25 & Q017030M1 & $1,203,494$ & 679,968 & $\mathrm{qp}_{1}$ & $-6.7 \pm 0.11$ & $-44.8 \pm 0.8$ & $0.24 \pm 0.19$ & $-15.92 \pm 0.27$ & $90.07 \pm 1.02$ \\
\hline 26 & Q003340 & $1,200,775$ & 670,715 & $\mathrm{qp}_{2-3}$ & $-6.86 \pm 0.09$ & $-43.3 \pm 1.3$ & $0.39 \pm 0.18$ & $-19.29 \pm 0.34$ & $92.35 \pm 0.83$ \\
\hline 27 & KT1-A & $1,239,796$ & 659,608 & $\mathrm{n}_{2}^{2}$ & $-6.8 \pm 0.13$ & $-47.3 \pm 1.2$ & $0.42 \pm 0.14$ & $-19.03 \pm 0.4$ & $88.7 \pm 0.95$ \\
\hline 28 & KT1-B & $1,239,796$ & 659,608 & $\mathrm{qp}_{2-3}$ & $-6.09 \pm 0.06$ & $-39.9 \pm 1$ & $0.92 \pm 0.15$ & $-12.68 \pm 0.28$ & $98.05 \pm 1.91$ \\
\hline 29 & KT9-1-A & $1,240,146$ & 659,375 & $\mathrm{qp}_{1}$ & $-6.78 \pm 0.08$ & $-45.1 \pm 1.2$ & $0.81 \pm 0.28$ & $-16.76 \pm 0.28$ & $97.85 \pm 1.69$ \\
\hline
\end{tabular}


Table 3 The isotopic composition of groundwater in the aquifers of the Southeast region (rainy season).

\begin{tabular}{|c|c|c|c|c|c|c|c|c|c|}
\hline $\mathrm{N}^{\mathrm{o}}$ & Number of works & $\mathrm{X}(\mathrm{m})$ & $\mathrm{Y}(\mathrm{m})$ & Aquifer & $\delta^{18} \mathrm{O}$ & $\delta^{2} \mathrm{H}$ & ${ }^{3} \mathrm{H}$ & $\delta 13 \mathrm{CVPDB}(\%)$ & PM \\
\hline 1 & AM1 & 1,25 & 0 & $\mathrm{p}_{3}$ & - & -42 & 0 . & 3 & 3 \\
\hline 2 & . & 3 & 5 & $\mathrm{p}_{3}$ & 14 & -43.9 & .32 & & \\
\hline 3 & 02302 & 1,21 & 5 & $\mathrm{qp}_{3}$ & $-6.3 \pm 0.1$ & $-39.7 \pm 1.2$ & $0.79 \pm 0.11$ & \pm 0.34 & 1.14 \\
\hline 4 & Q023 & 1,21 & 8,145 & $\mathrm{qp}_{1}$ & $-7.11 \pm 0.13$ & $-47.7 \pm 1.5$ & $-0.12 \pm 0.18$ & \pm 0.41 & $=1.32$ \\
\hline 5 & Q02304ZM1 & $1,219,729$ & 648,145 & $\mathrm{n}_{2}{ }^{1}$ & $-7.44 \pm 0.08$ & $-48.4 \pm 1.1$ & $-0.58 \pm 0.18$ & $-20.41 \pm 0.52$ & $48.22 \pm 1.1$ \\
\hline 6 & Q023050M1 & 1,219 & 45 & $\mathrm{n}_{1}^{3}$ & $-7.51 \pm 0.09$ & $-49.1 \pm 1.2$ & $0.06 \pm 0.24$ & $-22.17 \pm 0.29$ & 44.62 \\
\hline 7 & 2B & 56 & 6,294 & $\mathrm{qp}_{3}$ & $-6.78 \pm 0.13$ & $-44.2 \pm 0.8$ & $1.18 \pm 0.22$ & $5 \pm 0.47$ & \\
\hline 8 & Q22002Z & 1,28 & 7,650 & $\mathrm{qp}_{2-3}$ & $-6.9 \pm 0.1$ & $-45.1 \pm 1.5$ & $0.88 \pm 0.18$ & 0.24 & 103.4 \\
\hline 9 & Q220040M1 & 1,282 & 607,647 & $\mathrm{qp}_{1}$ & $-7 \pm 0.11$ & $-45.5 \pm 0.9$ & $0.55 \pm 0.24$ & $-19.89 \pm 0.37$ & 95.69 \\
\hline 10 & Q220050M1 & 1,28 & 07,646 & $\mathrm{n}_{2}{ }^{1}$ & $-7.72 \pm 0.12$ & $-51.6 \pm 0.9$ & $-0.05 \pm 0.23$ & $-18.89 \pm 0.41$ & $45.21 \pm 1.28$ \\
\hline 11 & ก020 & 1,25 & 6 & $\mathrm{qp}_{3}$ & $-6.34 \pm$ & $-40.4=$ & 1.2 & -19 & 2.08 \\
\hline 12 & र्य & 30 & & $\mathrm{qp}_{1}$ & $-7.31 \pm 0.1$ & $-49.1 \pm 1.2$ & $0.14 \pm 0.21$ & $-19.64 \pm 0.49$ & 86.5 \\
\hline 13 & Q22 & 1,25 & 93 & $\mathrm{n}_{2}^{2}$ & $-7.71 \pm 0.15$ & $-51.5 \pm 1.1$ & $0.02 \pm$ & $-21.07 \pm 0.33$ & $42.8 \pm 1.16$ \\
\hline 14 & Q222020 & 1,245 & 4,715 & $\mathrm{qp}_{3}$ & $-6.76 \pm 0.07$ & $-46 \pm 1.4$ & $1.21 \pm 0.13$ & \pm 0.38 & $105.05 \pm 1.83$ \\
\hline 15 & Q222040 & $1,245,789$ & 04,715 & $\mathrm{n}_{2}^{2}$ & $-7.62 \pm 0.13$ & $-49.9 \pm 1.1$ & $-0.15 \pm 0.29$ & $-13.51 \pm 0.42$ & $6.13=$ \\
\hline 16 & Q22 & 95 & & $\mathrm{n}_{1}^{3}$ & $-7.14 \pm$ & -44 & 0.1 & -20 & 69 \\
\hline 17 & $\Omega$ & & & $\mathrm{qp}_{2-3}$ & -7 & -45 & 3 & -11 & \\
\hline 18 & Q224020 & 1,228 & 37 & $\mathrm{qp}_{2-3}$ & $-6.83 \pm 0.14$ & $-44.3=$ & $1.06=$ & \pm 0.29 & 101.0 \\
\hline 19 & Q22404T & $1,228,847$ & 676,586 & $\mathrm{n}_{2}^{2}$ & $-7.13 \pm 0.07$ & $-46.7 \pm 1.5$ & $-0.19 \pm 0.15$ & $-20.73 \pm 0.29$ & $91.02 \pm 1.29$ \\
\hline 20 & Q804020 & $1,215,192$ & 664,143 & $\mathrm{qp}_{3}$ & $-6.18 \pm 0.13$ & $-38.4 \pm 1.2$ & $1.12 \pm 0.24$ & $-7.09 \pm 0.33$ & $101.93 \pm 2.91$ \\
\hline 21 & Q80404T & 1,21 & 664 & $\mathrm{n}_{2}^{2}$ & $-7.08 \pm 0.08$ & $-45.7 \pm 1.4$ & $0.17 \pm$ & $-19.8 \pm 0.47$ & $73.51 \pm 2.87$ \\
\hline 22 & Q80404ZM1 & 1,215 & 64,143 & $\mathrm{n}_{2}{ }^{1}$ & $-7.27 \pm 0.12$ & $-48.7 \pm 0.9$ & $0.07 \pm 0.3$ & \pm 0.41 & 32.7 \\
\hline 23 & Q00202B & 1,214 & 79,494 & $\mathrm{qp}_{2-3}$ & $-6.92 \pm 0.09$ & $-46.5 \pm 1.1$ & $1 \pm 0.14$ & \pm 0.51 & $96.63 \pm 1.32$ \\
\hline 24 & Q00204A & $1,214,360$ & 679,461 & $\mathrm{qp}_{1}$ & $-7.18 \pm 0.11$ & $-46.8 \pm 1$ & $0.25 \pm 0.33$ & $-18.93 \pm 0.25$ & $86.7 \pm 1.08$ \\
\hline 25 & Q017030M1 & $1,203,494$ & 679,968 & $\mathrm{qp}_{1}$ & $-6.92 \pm 0.07$ & $-46.7 \pm 1.4$ & $0.11 \pm 0.09$ & $-17.01 \pm 0.84$ & $89.09 \pm 1.34$ \\
\hline 26 & Q003340 & $1,200,775$ & 670,715 & $\mathrm{qp}_{2-3}$ & $-6.54 \pm 0.08$ & $-43 \pm 1.5$ & $0.6 \pm 0.21$ & $-19.83 \pm 0.34$ & $92.84 \pm 1.25$ \\
\hline 27 & KT1-A & $1,239,796$ & 659,608 & $\mathrm{n}_{2}^{2}$ & $-6.96 \pm 0.1$ & $-45.1 \pm 1.4$ & $0.31 \pm 0.19$ & \pm 0.29 & $88.25 \pm 1.26$ \\
\hline 28 & KT1-B & $1,239,796$ & 659,608 & $\mathrm{qp}_{2-3}$ & $-6.39 \pm 0.07$ & $-40.9 \pm 1.2$ & $0.58 \pm 0.21$ & $-11.73 \pm 0.3$ & $77.36 \pm 5.97$ \\
\hline 29 & KT9-1-A & $1,240,146$ & 659,375 & $\mathrm{qp}_{1}$ & $-6.7 \pm 0.09$ & $-44 \pm 1.5$ & $0.66 \pm 0.17$ & $-18.04 \pm 0.25$ & $96.87 \pm 2.01$ \\
\hline 30 & LKC3-qp1 & $1,253,153$ & 677,683 & $\mathrm{qp}_{1}$ & $-4.76 \pm 0.11$ & $-37.6 \pm 1.2$ & $0.71 \pm 0.16$ & $-17.29 \pm 0.38$ & $98.05 \pm 1.9$ \\
\hline 31 & LKC3-n22 & $1,253,153$ & 677,683 & $\mathrm{n}_{2}{ }^{2}$ & $-5.41 \pm 0.1$ & $-39.1 \pm 0.9$ & $0.52 \pm 0.19$ & $-12.32 \pm 0.3$ & $96.77 \pm 1.4$ \\
\hline
\end{tabular}

This finding in association with the results of the ${ }^{14} \mathrm{C}$ activity in DIC measurement for water in the upper Pleistocene aquifers (Table 2) reflected a fact that groundwater in these aquifers is modern and that it probably is continuously recharged from the surface water sources. In contrast, groundwater in the deeper aquifers did not receive recent recharge, therefore, it was of older ages, up to $22.5 \mathrm{ka}$ (Table 2).

Fig. 2a depicts the isotopic composition in all kinds of water: the local precipitation (RMWL_-Regional Meteoric Water Line), river's water, water from reservoirs and groundwater from all the study aquifers that was determined during the DS (Mar. 2015) in the SENB region. Fig. $2 b$ shows an extract of the Fig. $2 a$ to demonstrate more clearly the position of the isotopic composition in groundwater in relation to the composition of the surface water.

As seen from Fig. 2a, the line for the local precipitation (RMWL) follows a model described by Eq. (7).

$$
\delta^{2} H=6.71 \times \delta^{18} O+4.96\left(R^{2}=0.99\right)(7)
$$

The slope and intercept of the RMWL in the SENB region (Eq. (7)) are somewhat differed from those of the Global Meteoric Water Line of, respectively, 8 and 10 [32] due to the kinetic effect during the precipitation in the tropical regions where atmospheric temperature and humidity are usually high [5].

From Fig. 2b, the groundwater in the upper and 


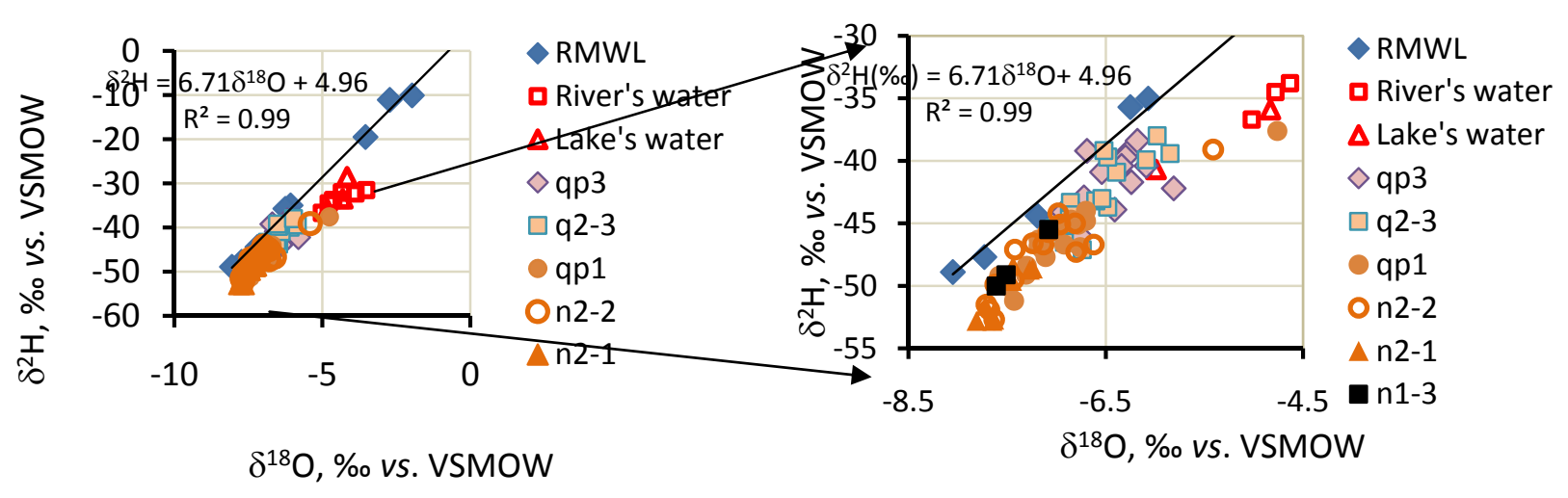

(a)

(b)

Fig. 2 The isotopic composition in all kinds of water with full scale (a) and an extract (b) from (a) for a more clearly demonstrating the position of isotopic content in groundwater samples in relation to the position of surface water.

middle Pleistocene $\left(\mathrm{qp}_{3}\right.$ and $\left.\mathrm{qp}_{2}{ }^{-3}\right)$ aquifers appears to be recharged from the surface sources, e.g. the local precipitation, from rivers or reservoirs because its isotopic composition was spread around the RMWL or the line of the surface water and it is modern by the ${ }^{14} \mathrm{C}$-age of around 104-105 PMC (Table 2). On the other hand, water in the rest aquifers $\left(\mathrm{qp}_{1}, \mathrm{n}_{2}{ }^{2}, \mathrm{n}_{2}{ }^{1}\right.$ and $\mathrm{n}_{1}{ }^{3}$ ) seems to be paleo-water as its isotopic composition is deviated from those of the RMWL (Fig. 2b) and its ${ }^{14} \mathrm{C}$-age was relatively old. Here, the paleo-water must be understood as groundwater having an elevated transit time (age), up to thousands years, but not like the definition made by Edmunds, W. M. [33] that paleo-water is the groundwater which is originated in the colder climatic conditions of the late Pleistocene. The ${ }^{14} \mathrm{C}$-age of groundwater in the $\mathrm{qp}_{2}{ }^{2}$, $\mathrm{qp}_{1}, \mathrm{n}_{2}{ }^{2}, \mathrm{n}_{2}{ }^{1}$ and $\mathrm{n}_{1}{ }^{3}$ aquifers in this study was found to range from 250 a (Q220040M1: $\left.\mathrm{qp}_{1}\right)$ to $22.5 \mathrm{ka}$ (Q222040: $\mathrm{qp}_{2}{ }^{2}$ ) (Table 2).

\subsection{Chemistry of Groundwater}

Groundwater in all the studied aquifers is fresh, containing low concentrations of $\mathrm{Cl}^{-}\left(<100 \mathrm{mg} \cdot \mathrm{L}^{-1}\right)$ and $\mathrm{SO}_{4}{ }^{2-}\left(<80 \mathrm{mg} \cdot \mathrm{L}^{-1}\right)$, and low content of TDS (Total Dissolved Solids) $\left(<340 \mathrm{mg} \cdot \mathrm{L}^{-1}\right)$. Fig. 3 depicts the distribution of the major electron-donor and acceptor ions with the depth of aquifers.
A calculation of the SI (Saturation Index) for calcite, dolomite and gypsum based on the $\mathrm{pH}$ and concentrations of $\mathrm{Ca}^{2+}, \mathrm{Mg}^{2+}, \mathrm{HCO}_{3}{ }^{-}$and $\mathrm{SO}_{4}{ }^{2-}$ in the samples (Table 1) showed that at the prevailing temperature of $25-30{ }^{\circ} \mathrm{C}$ in the aquifers, the three minerals are dissolving, as the $\mathrm{SI}_{\mathrm{cc}}<0$ and $\mathrm{Si}_{\mathrm{dol}}<0$, $\mathrm{SI}_{\text {gyp }}<0$ (results not shown here).

The chemical types of water in the study aquifers were identified by construction of Piper diagram based on the content of major cations of $\mathrm{Na}^{+}, \mathrm{K}^{+}, \mathrm{Ca}^{2+}$, $\mathrm{Mg}^{2+}$ and anions of $\mathrm{Cl}^{-}, \mathrm{HCO}_{3}{ }^{-}$and $\mathrm{SO}_{4}{ }^{2-}$ in water. The diagram was presented in Fig. 4 representing for the $\mathrm{Na}-\mathrm{Ca}-\mathrm{HCO}_{3}$ fresh water type for all the studied water samples.

In the aquifers, the following chemical reactions could be expected.

Decomposition of organic matters in the aquifers by enzymes:

$$
\begin{gathered}
4 \mathrm{CH}_{2} \mathrm{O}+2 \mathrm{H}_{2} \mathrm{O} \rightarrow \mathrm{CH}_{3} \mathrm{COOH}+ \\
\mathrm{HCOOH}+3 \mathrm{H}_{2}+\mathrm{CO}_{2}
\end{gathered}
$$

In the degradation (reaction (1)), nitrogen as one of the constituents of organic matters will be released as ammonia $\left(\mathrm{NH}_{4}^{+}\right)$. On the other hand, organic matters in the aquifer sediment will reduce Fe-oxide, and might be goethite and sulphate as reaction (2):

$$
\begin{gathered}
\mathrm{CH}_{2} \mathrm{O}+6 \mathrm{Fe}(\mathrm{OH})_{2}+7 \mathrm{H}^{+} \rightarrow 6 \mathrm{Fe}^{2+}+ \\
\mathrm{HCO}_{3}{ }^{-}+6 \mathrm{H}_{2} \mathrm{O}
\end{gathered}
$$




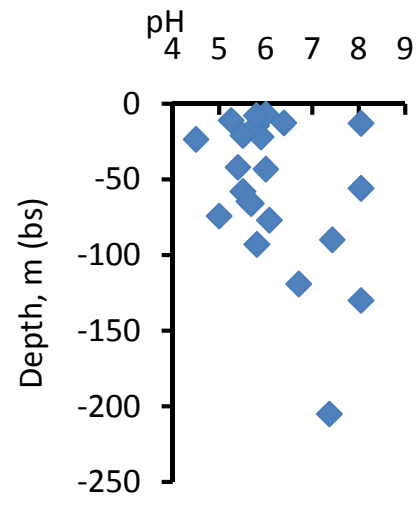

(a)

$\left[\mathrm{SO}_{4}^{2-}\right], \mathrm{mg} \cdot \mathrm{L}^{-1}$

$\begin{array}{llll}0 & 10 & 20 & 30\end{array}$

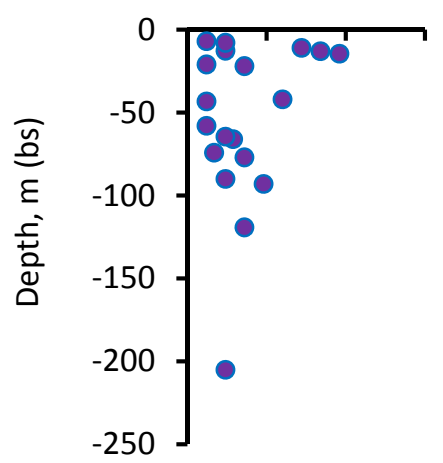

(c)
$\left[\mathrm{NO}_{3}^{-}\right], \mathrm{mg} \cdot \mathrm{L}^{-1}$

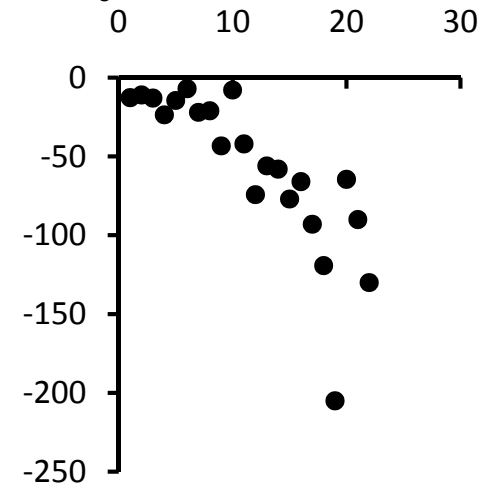

(b)

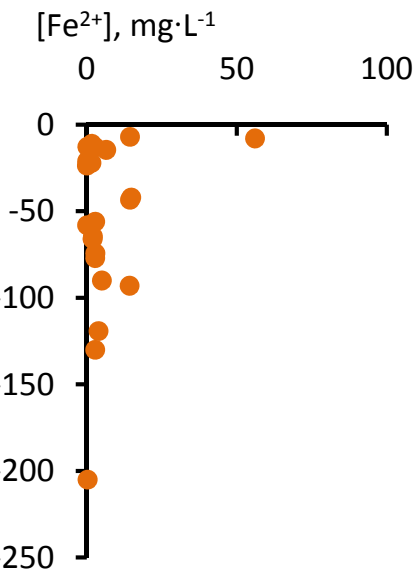

(d)

Fig. 3 The distribution of major electron-donor $\left(\mathrm{Fe}^{2+}\right)$ and acceptors $\left(\mathrm{pH}, \mathrm{SO}_{4}{ }^{2-}\right.$ and $\left.\mathrm{NO}_{3}{ }^{-}\right)$along the depth of aquifer.

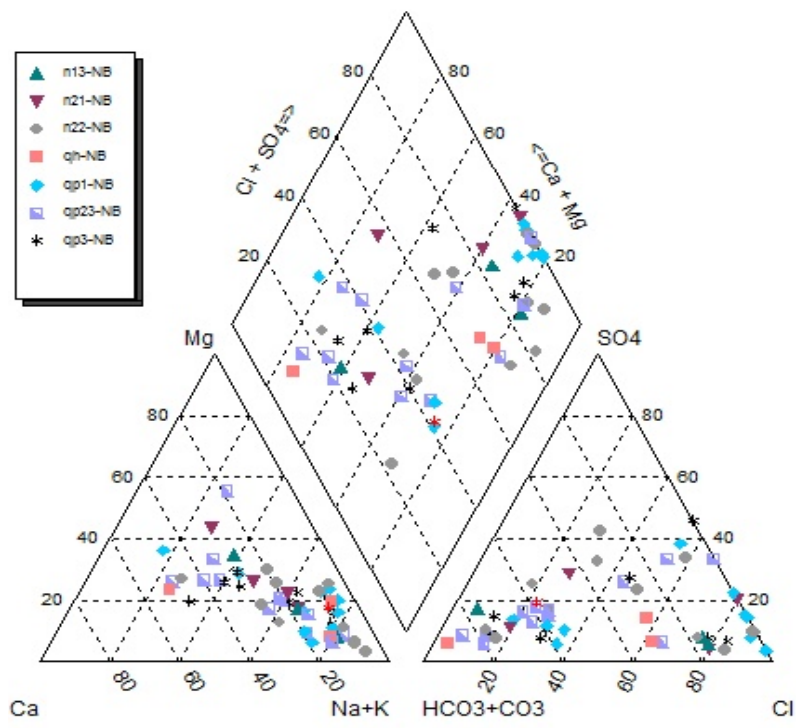

Fig. 4 A Piper diagram showing a Na-Ca- $\mathrm{HCO}_{3}$ fresh water type of groundwater in the SENB region.

$$
2 \mathrm{CH}_{2} \mathrm{O}+\mathrm{SO}_{4}{ }^{2-} \rightarrow \mathrm{HS}^{-}+2 \mathrm{HCO}_{3}^{-}+\mathrm{H}^{+}
$$

Ferrous ions formed in the reaction (2) could precipitate with sulfide from the reaction (3) in the form of pyrite $\left(\mathrm{FeS}_{2}\right)$. Sulphate ions in the reaction (3) could be formed from the gypsum dissolution:

$$
\mathrm{CaSO}_{4} \rightarrow \mathrm{Ca}^{2+}+\mathrm{SO}_{4}{ }^{2-}
$$

\subsection{Flow Direction of Water in the Aquifers}

Figs. 5a and 5b depict the isolines of water hydraulic head measured for the lower Pleistocene $\left(\mathrm{qp}_{1}\right)$ and upper Pliocene $\left(\mathrm{n}_{2}^{2}\right)$ aquifers, respectively. The difference of the hydraulic head indicates the direction of water flow within an aquifer as shown by the arrows in Figs. $5 \mathrm{c}$ and $5 \mathrm{~d}$ for the respective aquifers in the SENB region. As seen that groundwater in the study region flows northerly towards 


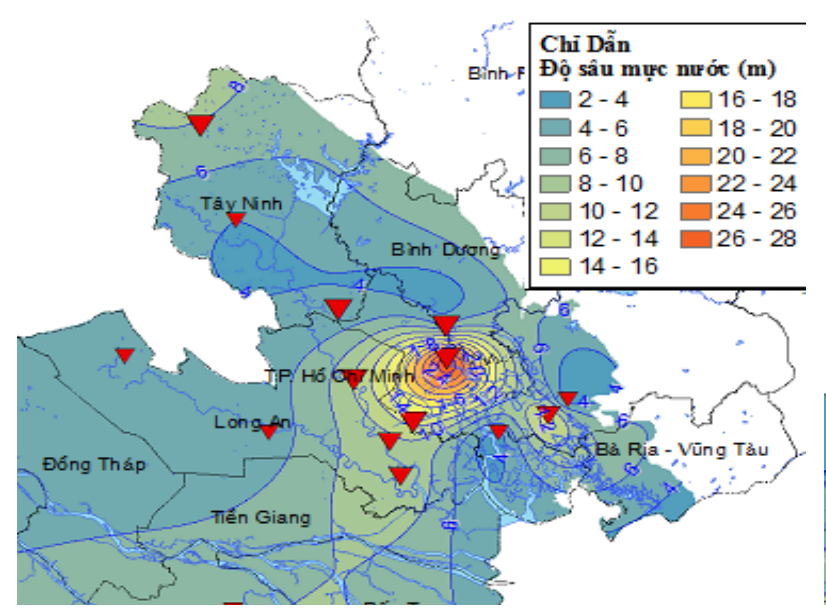

(a)

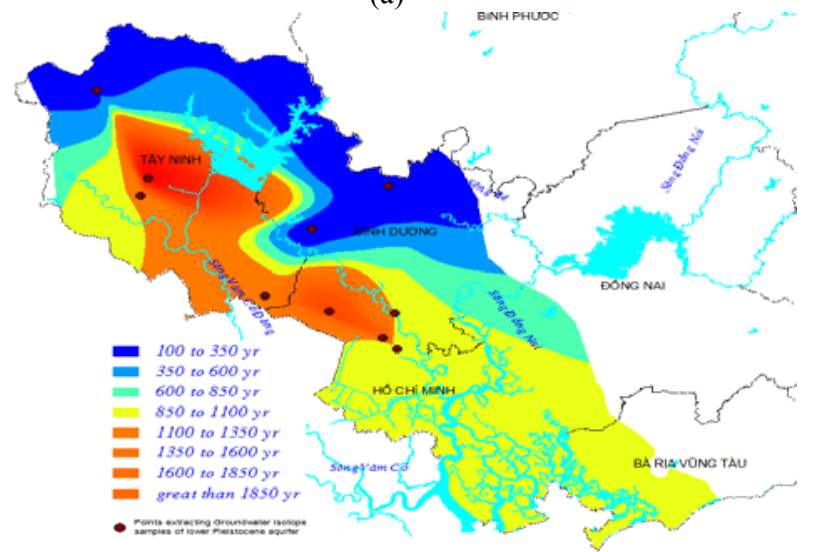

(c)

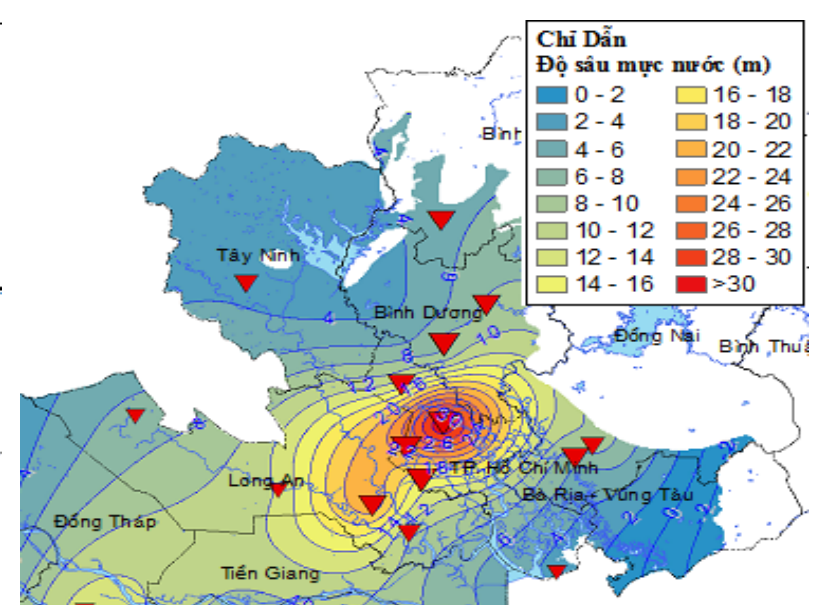

(b)

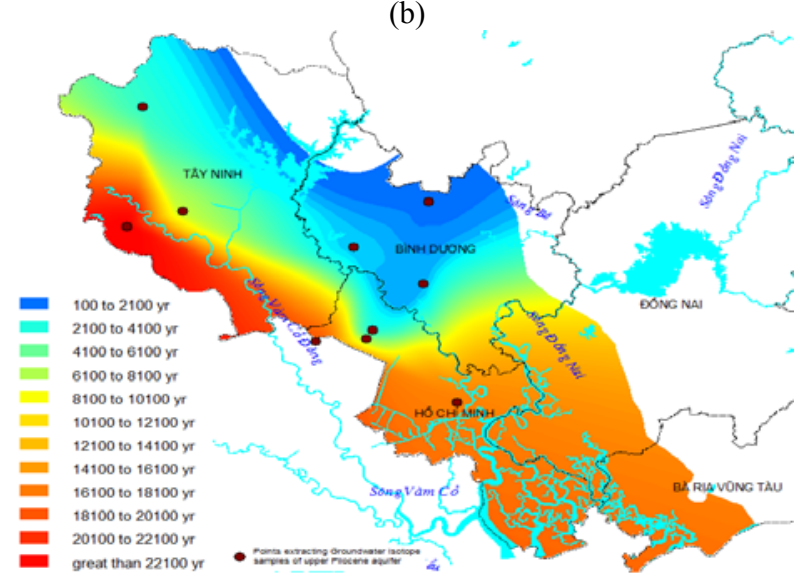

(d)

Fig. 5 Isolines of hydraulic heads for the lower Pleistocene $(a, b)$ and upper Pliocene aquifers indicating the flow direction of groundwater in the respective aquifers which was confirmed by the ${ }^{14} \mathrm{C}$-isochrones for the respective aquifers (c) and (d).

southerly and northeasterly towards southwesterly.

\section{Discussions}

5.1 Genesis of Groundwater Resources in the SE SP Region

As can be seen from Fig. 2b, the groundwater in the Pleistocene and Neogene aquifers in the SE SP region seems to be of paleo-origin as it is isotopic compositions lying separately from the RMWL and line for water from rivers or lakes. The paleo concept in here must be understood that water has relatively long resident time, but not that water that was originated from the Latest Glacial Maximum as it was mentioned early. The ${ }^{14} \mathrm{C}$-age of water in almost all the boreholes made into Pleistocene and Neogene aquifers was of about thousand years (Table 2), e.g. water in the borehole Q222040 made in the upper Pliocene aquifer has a ${ }^{14} \mathrm{C}$-age as old as $22.4 \mathrm{ka}$. Paleo-water was characterized by a line parallel to the meteoric water line and as farer the position of this line relative to the RMWL the older age of water is [5, $26]$.

In contrast, water in the upper Pleistocene and Holocene aquifers seems to be recharged from the local hydrological systems like Sai Gon-Dong Nai rivers or Dau Tieng reservoir. Water in the boreholes made into the Holocene or upper Pleistocene aquifers contains tritium activity that was comparable to those found in the local precipitation and in water of the reservoirs and it was modern by the ${ }^{14} \mathrm{C}$-age (Table 2). The upper Pleistocene was outcrop in many locations in the SE SP region at an altitude hight, so the 
precipitation could easily percolate into the aquifers.

A statistical treatment to compare means of the $\delta^{18} \mathrm{O}$ signature in water in two adjacent aquifers using a non-parametric test, the Mann-Whitney test, showed that in the study region, the groundwater in aquifers was separated from each other, e.i. there is no inter-aquifer leakage as the difference of $\delta^{18} \mathrm{O}$ mean between two adjacent aquifers is significant, $Z>1.96$, the critical value at a $5 \%$ limit. This allows to estimate the altitude of recharge areas for the aquifers based on an altitude gradient of $-0.3 \%$ per $100 \mathrm{~m}$ height. Considering that the mean of $\delta^{18} \mathrm{O}$ in the local precipitation is $5.44 \%$ (Fig. 2a), and that in water in the lower Pleistocene aquifer is $-7.00 \%$ and in the upper Pliocene aquifer is $7.49 \%$ (Table 2), the recharge area for the $\mathrm{qp}_{1}$ aquifer is estimated at about $520 \mathrm{~m}$ and that for the $\mathrm{n}_{2}{ }^{2}$ aquifer at about $680-700 \mathrm{~m}$ higher than the altitude of the respective aquifers.

\subsection{Degradation of Organic Matters and Chemistry of Groundwater in the SE SP Region}

The chemistry of the groundwater in the SE SP region is likely controlled by the organic matter degradation following a classical redox proceeding sequentially through different electron acceptors [34]. After the reduction of dissolved oxygen in the uppermost soil layer, nitrate becomes reduced (Fig. 3b). This is again followed by the reduction of Fe-oxides and sulfate (Figs. 3c and 3d). In this case, nitrate reduced in a soil layer of 5 to $10 \mathrm{~m}$ below the surface (bs), but afterwards, it again moved downwards and attained equilibrium at the depth of $60-80 \mathrm{~m}$ (bs), with the concentration of around 20 $\mathrm{mg} \cdot \mathrm{L}^{-1}$. The reason for this is still not clear, however, it was thought that in the deep aquifers, nitrate was resulted from the ammonia oxidation by sulphate. The presence of sulphate ions in the groundwater in this region where there was no marine deposit probably was the result of the gypsum dissolution (reaction (4)) as it was evident from Fig. 6 where it depicted a scatter plot of $\left[\mathrm{Ca}^{2+}\right]-\left[\mathrm{SO}_{4}{ }^{2-}\right]$. In this plot, the $\left[\mathrm{Ca}^{2+}\right]$ is correlated with $\left[\mathrm{SO}_{4}{ }^{2-}\right], \mathrm{r}^{2}=0.5(\mathrm{n}=28)$ and in groundwater samples, the $\left[\mathrm{Ca}^{2+}\right]$ is around 2 time higher than $\left[\mathrm{SO}_{4}{ }^{2-}\right]$ suggesting the calcite dissolution is another source of calcium in the studied groundwater.

Most of the groundwater samples in the study region are acidic with a $\mathrm{pH}$ ranging around 5-6, not following any trend in relation to the depth of aquifers (Fig. 3a). Geology of the region (Fig. 1b) showed that the aquifers deposit consists mostly of sand containing disseminated fragments of organic materials. The main crop in this region is rubber and the local farmers rarely fertilize the crop during the entire crops life. Apparently, the existence of ammonia and nitrate in the groundwater in the region does not imply the source of the nutrients is an anthropogenic rather than a natural one. Nitrogen compounds contained in natural organic matter and upon decomposition is released as ammonia to the groundwater. The degradation of organic matter will cause $\mathrm{pH}$ in water to decrease (reaction (1)) as observed in this case. Organic matter not only decomposes in aquifers but it also participates in the reduction of Fe-oxides and sulphate (reactions $(2,3)$ ). Therefore, it could be expected that the concentration of ammonia in groundwater would increase with the increase of the concentration of $\left[\mathrm{Fe}^{2+}\right]$ in water. A trend of the $\left[\mathrm{Fe}^{2+}\right]$ vs. $\left[\mathrm{NH}_{4}^{+}\right]$in groundwater in the $\mathrm{SENB}$ region is presented in Fig. 7.

It is clear that the organic matter decomposition

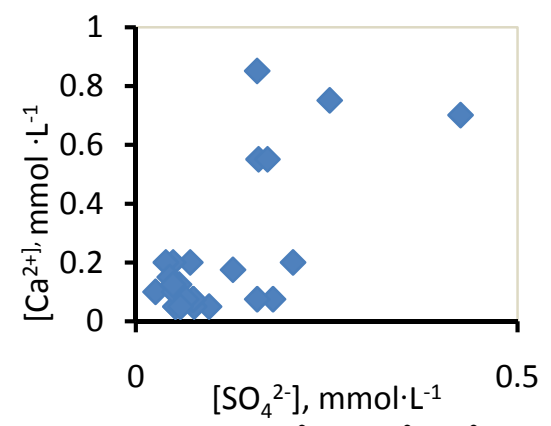

Fig. 6 A scatter plot of $\left[\mathrm{Ca}^{2+}\right]-\left[\mathrm{SO}_{4}{ }^{2-}\right]\left(\mathrm{r}^{2}=0.5, \mathrm{n}=28\right)$ showing the presence of sulphate ion in groundwater in the study region was a result of the gypsum dissolution (reaction (4)). 


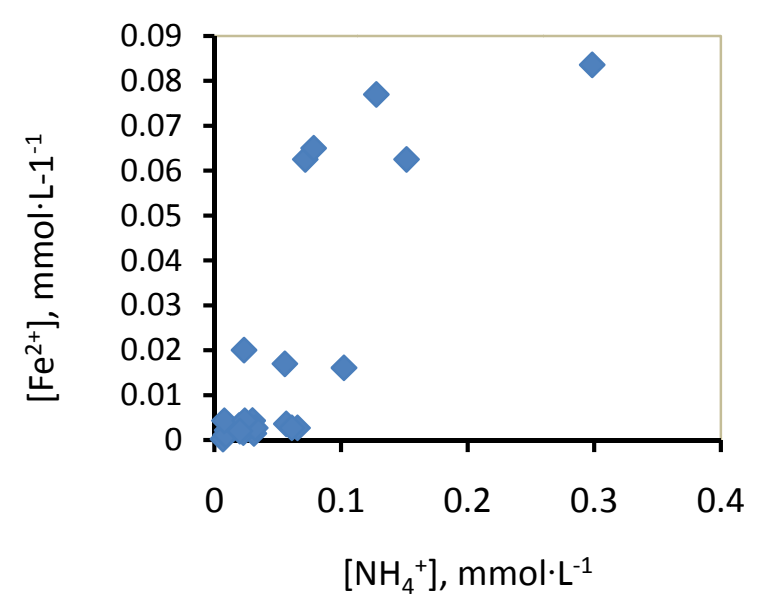

Fig. 7 A scatter plot of $\left[\mathrm{Fe}^{2+}\right]-\left[\mathrm{NH}_{4}^{+}\right]\left(\mathrm{r}^{2}=0.65, \mathrm{n}=25\right)$ showing the two constituents were originated from the organic matter decomposition in groundwater in the SENB region.

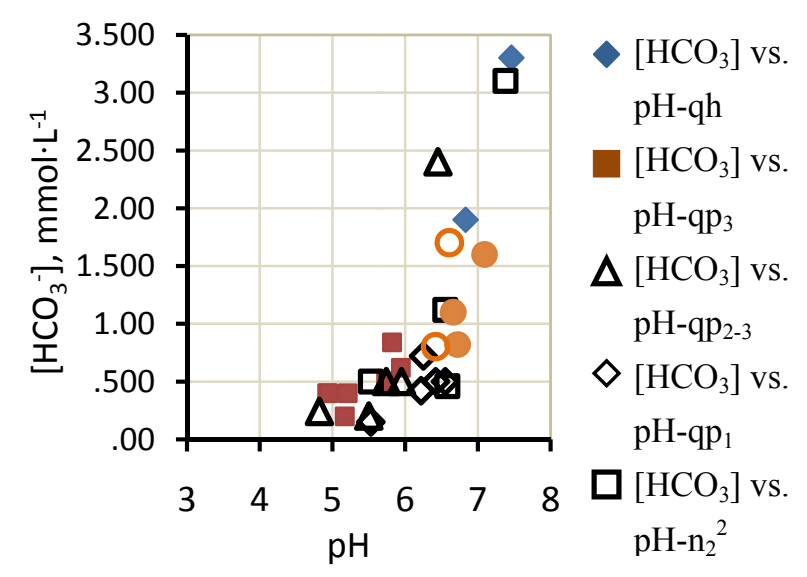

Fig. 8 pH controlling the bicarbonate concentrations in groundwater in different aquifers in the SENB region.

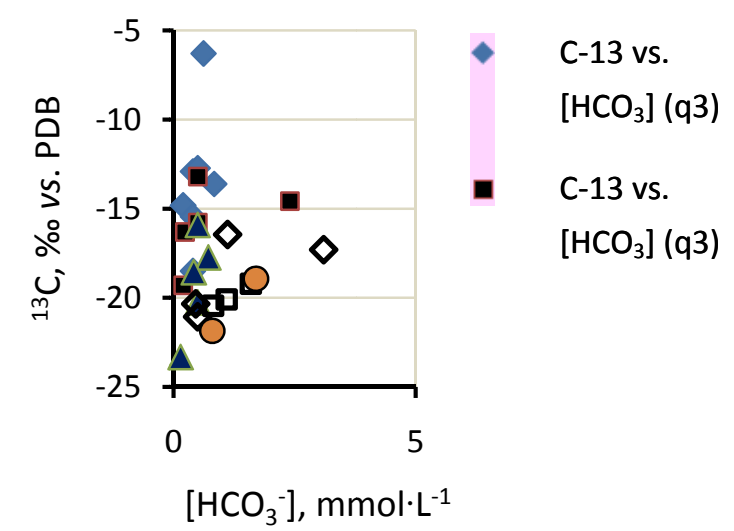

Fig. 9 Bicarbonate in groundwater from different aquifers in the SE SP region is a mixture of inorganic (calcite dissolution) and organic (organic matter decomposition and oxidation) sources. (reaction (1)) and oxidation (reactions $(2,3)$ ) will be $\mathrm{pH}$ dependent processes (reactions (1-3)). One of the products of the reactions (1-3) is bicarbonate so that the bicarbonate concentration in groundwater should be controlled by the $\mathrm{pH}$ as it was seen in Fig. 8 .

Obviously, the DIC in groundwater must be of organic and inorganic origins. The organic DIC comes from the decomposition and oxidation of organic matter, but the inorganic DIC comes from dissolution of calcite and/or dolomite that always presented in the aquifer deposit. In the SE SP region, aquifer sediment was terrestrial but not marine origin, hence, the sediment contained only organic matter of high plants. It is known that the ${ }^{13} \mathrm{C}$-composition $\left({ }^{13} \mathrm{C}\right)$ of the organic matter should be around -23\%o [34] as the plants usually were the C3-type grown in the tropical region. It was expected that the DIC representing by the bicarbonate concentration in groundwater must be a mixture of the organic and inorganic carbonate. The inorganic bicarbonate must have ${ }^{13} \mathrm{C}$ around 0 by the definition (Eq. (3)). Fig. 9 is an evidence for the mixing of inorganic and organic bicarbonates in different aquifers in the SE SP region.

Apparently, the contribution of each bicarbonate source to the total bicarbonate content in the groundwater was different and dependent to the content of inorganic carbonate and active organic matter in each aquifer. However, in the study region, the contribution of bicarbonate from organic source was dominant as seen in Fig. 9 in which the ${ }^{13} \mathrm{C}$-composition in DIC was depleted and far from 0 being the ${ }^{13} \mathrm{C}$ in calcite.

\section{Conclusion}

Groundwater resource in the SE SP region, Vietnam was found in 7 aquifers: the Holocene, upper, middle and lower Pleistocene, upper and middle Pliocene and Miocene ones. The water resource there seems to be recharged from northern and northwestern areas at an altitude of $600-700 \mathrm{~m}$ higher than the elevation of the Pleistocene and Pliocene aquifers. The 
transit time of the groundwater in the region ranged from several hundred to several thousand years ago. The groundwater in the study region is considered clean with less than $300 \mathrm{mg} \cdot \mathrm{L}^{-1}$ TDS and the chemistry of the water is controlled by the redox reactions proceeded from the organic matter decomposition.

At present, the inter-aquifer leakage in the study region was not observed yet, however, it could be expected that the inter-aquifer leakage could happen in future due to the increasing abstraction rate of groundwater in this intensive industrializing region. Therefore, a proper policy for groundwater resource management needs to be developed for protecting the natural resource from the risk of pollution from the surface.

\section{Acknowledgement}

The corresponding author would like to express sincere gratitude to the financial support from the Ministry of Natural Resources and Environment, Vietnam within a research project entitled "Study on the Neogene-Quaternary Structural Characteristics of the South East Region and Their Role in the Formation of Groundwater Reserves in the Southern Plain". The authors are heartily thankful to the anonymous reviewers for their patience and time to read and make comments for the manuscript.

\section{References}

[1] Cuong, N. K. 1995. "Groundwater in the Cuu Long (Mekong) River Delta." Presented at a National Forum on "Groundwater Resources in Vietnam", Ho Chi Minh City.

[2] Nghi, V. V., and Weslling, H. 1981. "Assessment of Groundwater in Quantity and Quality in the Mekong Delta." The Mekong River Committee, BangKok, Thailand.

[3] Louvat, D., and Dung, H. H. 1989. Environmental Isotope Study of Mekong River Delta Groundwater (Vietnam). A report for the IAEA TC Project VIE/8/003, IAEA-RU-2813.

[4] Mook, W. G., Bommerson, J. C., and Staverman, W. H. 1974. "Carbon Isotope Fractionation between Dissolved
Bicarbonate and Gaseous Carbon Dioxide." Earth and Planetary Science Letters 22 (2): 169-76.

[5] Clark, I. D., and Fritz, P. 1999. Environmental Isotopes in Hydrology. NY: CRC Press, 328.

[6] Vinh, C. T., Canh, D. V., Chinh, N. K., Nhan, D. D., and Phuong, N. T. 2015. "Studying the Formation of Exploitation Reverse of Groundwater Resouces from Leakage of Aquifer in Nam Bo Plain by Isotopic Techniques." Vietnam National University Journal and Science: $286-94$.

[7] Pho, N. V., Tuan, V. V., and Xuan, T. T. 2003. "Water Resouces in Vietnam." Agricultural Publisher, Hanoi: 139-41.

[8] Dzanh, T. 1986. "Review of the Paleogene and Neogene Stratigraphy in Vietnam, Laos and Kampuchea." Geology of Kampuchea, Laos and Vietnam. Science Technical Publisher House, Hanoi: 86-93.

[9] Nam, T. N. 1995. "The Geology of Vietnam: A Brief Summary and Problems." Geoscience Reports of Shizuoka University 22: 1-9.

[10] DWRPIS (Division for Water Resources Palanning and Investigation for the South of Vietnam). 2004. Separation of $\mathrm{N}-\mathrm{Q}$ Strata and Investigation into the Geologic Structure of the NBP at a Scale of 1:500.000. A report for a Project Conducted by the Division during 2004.

[11] Dzung, N. D. 2013. "Size, Shape and Dispersion: Urban Form Evolution in Saigon River Basin and Its Impacts on Hydrologic Performance from 1990 to 2010.” Presented at the 49th ISOCARP (Intl. Society Of City And Regional Planners), Brisbane, Australia.

[12] IMHEN (Institute of Meteorology, Hydrology and Environment). 2010. The Impact of the Climate Change on Water Resources and Adaptation Measures: Mekong River Delta. Final report of a Project Sponsored by the Danish Ambassy in Vietnam (in Vietnamese), 135.

[13] Stumm, W., and Morgan, J. J. 1981. Aquatic Chemistry (2nd Edition). New York: Wiley \& Sons, 780.

[14] Stookey, L. L. 1970. "Ferrozine-A New Spectrophotometric Reagent for Iron.” Anal. Chem. 42 (7): 779-81.

[15] IAEA (International Atomic Energy Agency). 2002. "Water and Environment Newsletter of the Isotope Hydrology Section.” IAEA 16 (Nov.): 5.

[16] Gonfiantini, R. 1984. "Stable Isotope Reference Samples for Geochemical and Hydrological Investigations, Report by Advisory Group's Meeting, Vienna, 19-21 September 1983." International Atomic Energy Agency (IAEA), Vienna.

[17] Villa, M., and Manjon, G. 2004. "Low-Level Measurements of Tritium in Water." Appl. Radiat. and Isotopes 61 (2): 319-23.

[18] Plastino, W., Chereji, I., Cuna, S., Kaihola, L., De Felice, 
P., Lupsa, N., et al. 2007. "Tritium in Water Electrolytic Enrichment and Liquid Scintillation Counting." Radiat. Meas. 42 (1): 68-73.

[19] Groening, M., Dargier, M., and Tatzber, H. 2004. "Seventh IAEA Intercomparison of Low-Level Tritium Measurement in Water (TRIC2004)." International Atomic Energy Agency, Vienna.

[20] Groening, M., Tatzber, H., Trinkl, A., Klaus, B., and van Duren, M. 2009. "Eighth IAEA Interlaboratory Comparison on the Determination of Low-Level Tritium Activities in Water (TRIC2008)." International Atomic Energy Agency, Vienna.

[21] Noakes, J. E., Isbell, A. F., Stipp, J. J., and Hood, D. W. 1963. "Benzene Synthesis by Low Temperature Catalysis for Radiocarbon Dating." Geochim. et Cosmochimica Acta 27 (7): 797-804.

[22] Noakes, J., Kim, S., and Akers, L. 1967. "Recent Improvements in Benzene Chemistry for Radiocarbon Dating." Geochim. et Cosmochimica Acta 31 (6): 1094-6.

[23] Tamers, M. A. 1975. "Chemical Yield Optimization of the Benzene Synthesis for Radiocarbon Dating." The Intl. J. Appl. Radiat. and Isotopes 26 (11): 676-82.

[24] Gupta, S. K., and Polach, H. A. 1985. "Radiocarbon Datirig Practices at ANU." Radiocarbon Laboratory, Research School of Pacific Studies, ANU, Canberra, 173.

[25] Mann, W. B. 1983. "An International Reference Material for Radiocarbon Dating.” Radiocarbon 25 (2): 519-27.

[26] Mook, W. G., ed. 2001. "Environmental Isotopes in the
Hydrological Cycle. Principles and Applications. IHP TecDoc 39." UNESCO/IAEA, Paris/Vienna, 280.

[27] Salem, O., Visser, J. M., Deay, M., and Gonfiantini, R. 1980. "Groundwater Flow Patterns in the Western Lybian Arab Jamahitiya Evaluated from Isotope Data." Arid Zone Hydrology: Investigation with Isotope Techniques, IAEA, Vienna: 165-79.

[28] Bigeleisen, C. T., and Mayer, M. G. 1947. "Calculation of Equilibrium Constants for Isotopic Exchange Reactions." The Journal of Chemical Physics 15 (5): 261-7.

[29] Fontes, J. C., and Garnier, J. M. 1979. "Determination of the Initial ${ }^{14} \mathrm{C}$ Activity of Total Dissolved Carbon: A Review of Existing Models and a New Approach." Water Resources Research 15 (2): 399-413.

[30] Fontes, J. C. 1983. Dating of Groundwater. Guidebook on Nuclear Techniques in Hydrology. Tech. Rep. Ser. 91, IAEA, Vienna, Austria, 285-317.

[31] Ferronskii, V. I., ed. 1975. Natural Isotopes of Hydrosphere (In Russian). Nedra, Moscow, 280.

[32] Craig, H. 1961. "Isotopic Variations in Meteoric Waters." Science 133 (3465): 1702-3.

[33] Edmunds, W. M. 2001. "Palaeowaters in European Coastal Aquifers-The Goals and Main Conclusions of the PALAEAUX Project." Geological Society, London, Special Publications 189 (1): 1-16.

[34] Appelo, C. A. J., and Postma, D. 2007. Geochemistry, Groundwater and Pollution (2nd Edition)." CRC Press. 